\title{
Symbolic and Gender Boundaries among the Bolsa Familia Beneficiaries
}

\author{
Mani Tebet \\ Department of Social Sciences, Federal Rural University of Rio de Janeiro, Brazil
}

Copyright $\bigcirc 2017$ by authors, all rights reserved. Authors agree that this article remains permanently open access under the terms of the Creative Commons Attribution License 4.0 International License

\begin{abstract}
The present article intends to ascertain to what extent the "Bolsa Família" allowance program modifies gender, power and interest relations to beneficiary couples a topic that has aroused very little interest in public and academic debate. This paper also attempts to identify and understand moral and symbolic effects that the policy can produce on family and gender relations; the criteria of justice put forward by the couples for "deserving" the Bolsa Família benefit; and the rationale that underlies this notion of merit. Interviews were conducted with 30 couples in a district in the metropolitan region of Rio de Janeiro.
\end{abstract}

Keywords Poverty, Gender, Income Transfer

\section{Introduction}

Debates about income transfer are not recent; nevertheless those programs have never had such an important role in fighting poverty in many countries. Despite numerous experiences that arose previously, it was in the 1980s that there was an intensification of discussions on such policies. Thus, the need for income transfer policies enters the international debates as a possible mechanism to fight hunger and poverty in the context of growth in the number of unemployed and socially vulnerable people. It is undeniable that such policies have entered strongly on the agenda of social protection, thus, cash transfer programs have been implemented by governments of varying ideological hues, and countries differ in political and state traditions. Specifically in Brazil the Bolsa Família Program (PBF) began in 2003 and it is presented as a monetary transfer policy to poor families, prioritizing women as responsible for the benefit. In 2011, the PBF supported over 13 million families, according to the Ministry of Social Development and Hunger Fighting. At international level, it is important to note that the program adopts some of the principles of the "Millennium Development Goals" set by the United Nations, which include the eradication of poverty.
In Brazil, such issue is addressed by two actions of the Bolsa Família Program: one, as emergency measure, aimed at poverty alleviation through direct cash transfers to poor families; also the exercise of basic social rights related to health and education, in order to break the intergenerational cycle of poverty reproduction. The program has two types of families as its target group: those with monthly per capita income of less than $\mathrm{R} \$ 70$ and those with per capita monthly income up to $R \$ 140$. In the first arrangement, any family setting is able to receive the income, even couples without children or one-person households. In the second, it is necessary that at least one pregnant woman or a nursing mother or a person between 0 and 17 years old composes the family for entering the program. It is important to mention that the benefit amount may vary according to the monthly per capita family income and to the number of people up to 17 years old. Moreover, the amount transferred covers up to five children between 0 and 15 years old and up to two teenagers between 16 and 17 years old. Consequently, a family may receive at least $R \$ 32$ and a maximum of $R \$ 306$ per month.

The planning of this program is based on the "empirical fact" that women are more dedicated to children than men are since they would have been socially educated for such purpose. This assumption is one of the most controversial aspects when discussing the PBF, precisely because there is a contradiction between the massive entry of women into the labor market and a reallocation of poor women to the traditional role of mother in order to benefit from the program. This point is discussed more precisely in the debate on policies classified as "familistic", "gendered" and / or "maternalistic". Public and academic debates about the PBF have been discussing other factors such as the effectiveness of focusing on poor people, the lack of "exit doors" out of assisted situation and food security, mainly. On the other hand, few studies are intended to sociologically analyze such a policy as a gendered social construction and its moral effects on beneficiary families. One of the few evaluations so far conducted on the PBF impacts on women or on gender issues [1] indicates a "women' $s$ empowerment" and their "status improvement" in society. However, we could say that 
in general there is a methodological problem in studies that aim to analyze gender relations, focusing on beneficiary women for being interviewed.

Overall, in the field of feminist and/or gender studies, the methodological guidance to consider women as the only research subject has been recurrent and a priority among the theorists. Obviously there is a political bias that interferes with the methodological approach of the object. This condition brings out a sociological issue that relates to the definition of the concept of gender. Therefore, if gender relations presuppose power relations, what is the point in only one of the actors involved in the relationships being focused in the research? That why we conducted 60 interviews with couples and beneficiaries of PBF residents of the municipality of Itaboraí, on the outskirts of the metropolitan area of Rio de Janeiro are reported.

According to data from a survey conducted by IBASE (2008: 65) on the PBF, in Brazil 61.9\% of holders are women with partner and children. Women without partners and children are $27.2 \%$. Men with partner and children are $4.8 \%$ of holders. In other words, from both theoretical and empirical approaches, there would be an unreliable sociological study of gender relations if we assumed that there was only one legitimate speech - in this case, from women - which could not be compared or even resisted. First, it is important that national and international literature related to the understanding of the connection between poverty and gender are presented, albeit briefly. The number of income transfer policies that prioritize women as intermediaries between society and state has grown worldwide - especially in Latin America -, even when those policies do not necessarily take the agenda "gender equality" as a goal to be achieved. Such orientation for current income transfer policies is certainly related to - among other aspects - the assumption of the so-called "feminization of poverty".

\subsection{Theoretical Perspective}

What is the meaning of "feminization of poverty"? The concept was coined by sociologist Diane Pearce [2], who perceived the rise of the absolute number of poor women and the growth of poverty among individuals who comprise households headed by women compared to those headed by men between the 1950s and 1970s, in the United States. In subsequent decades, other researchers ([3]; [4]; [5]) used similar concepts to the one of feminization of poverty. Still, Fuchs[6] defines that concept as the process of expansion of the female group among poor adults. The author supports that the phenomenon occurred in the US during the 1960s, what cannot be assumed about subsequent decades. In 1995, the United Nations Development Program (PNUD) outlined an overrepresentation $(70 \%)$ of women among the poor in the world in its "Human Development Report".

However, the idea that there was a poverty feminization process is not a consensus. In this sense, Marcoux [7] criticizes the statements of PNUD, pointing out that there would be a demographic problem if they were true. That same year, the World Conference in Beijing highlighted the discrepancy between the increase in the number of poor women in comparison to men. When it comes to the Brazilian context, Queiroz[8] points out that such claims are not supported by empirical evidence. There is a lack of studies on the subject; there are more focused studies on the causes of poverty and not enough discussion on the intensity, incidence and representation of poverty of women among the poor.

According to this author, the controversy is related to two fundamental discussions about the feminization of poverty. The first one links to the perception that there was an increase in the poverty rate among women. The second one points to an intensification of the condition of poverty among women. Queiroz [8] cites researches ([9]; [10]) showing that only in certain geographic areas it can be said that there is a process of feminization of poverty. Therefore, the idea of a global impoverishment of women, contained in reports and international documents, is mistaken. Referring to Dooley [11], the author shows that particularly in Canada the feminization of poverty occurred only between 1973 and 1990 , yet this situation only focused female role as head of the family and ignores any comparison of men and women in general. In Spain, for instance, Fernández-Morales and García-Haro[12]did not find any overrepresentation of women among the poor during the 1990s.

Furthermore, there is a methodological problem in measurements to capture poverty rates because they presuppose average household income, which merges the income of men and women in the household into one. Queiroz [8] points out that feminization of poverty is not only theoretically but also empirically controversial. There are also difficulties related to the definition of poverty considered as a phenomenon restricted to the scope of income. If poverty would be understood as being related to other aspects of social life such as education, sociability, forms of association, access to culture, among others, then the idea of feminization of poverty that prevails on female single parent family would not be so frequent.

The American theoretical Diane Pearce [2] defined the feminization of poverty in the late 1970s in the United States as a moment when women lose the spouse role to assume a householder position with children, being therefore responsible for the home. Pearce researches focused on determine the causes of the feminization of poverty. Therefore, remuneration sources (such as employment, social security, minimum income and alimony) were considered in order to infer why female-headed households would be poorer than male-headed ones. In fact, feminization of poverty is not only related to the position of women in family structure, but also with their position in the labor market, especially with regard to precarious employment, low wages and presence in the informal sector.

It has been consolidated among scholars in Brazil and all over the world the notion that families headed by women 
would lead to new families also in social vulnerability situation, being unable to break with the intergenerational cycle of poverty reproduction through time. That was one of the justifications for the implementation of programs and policies that take a priority focus on women as beneficiaries. It is noteworthy that in some Latin American countries there are gender concerning cash transfer policies. However, this guidance does not apply to $\mathrm{PBF}$, which is consolidated as a family welfare policy. In the last two decades, the social sciences produced at international level an important critical reflection on the welfare state whose public policy was ruled until recently by the duality of gender roles: men as breadwinners and women as caregivers, what strengthened the gender division in work market and especially the role of women as mothers. Between the late 1990s and early 2000s, researchers such as Esping-Andersen, Jane Janson, Ann Shola Orloff, Maxine Molyneux, started to produce works in the field of Sociology that aimed to analyze social protection policies from the theoretical perspective of gender. That meant building a critique of welfare state by demonstrating that even in the public sphere, where there might be a level of social equalization, gender inequality was reproduced within the social policies. This kind of reproduction has been classified in several ways: "familistic", "maternalistic" and / or "gendered".

Some problems regarding to this so-called "maternalistic" policy model are perceived by Orloff [13]. First, this kind of policy would reinforce the traditional gender division of labor. Second, it would maintain women's position of dependence on the male provider. As a result, women would only have access to the benefits of the welfare state by marital means, which, ultimately, would create an invisibility of female workers, who need social provision. Due to the increasing convergence of men and women participation rates in the labor market, educational attainment of women, and individualization and autonomy processes of women in many European countries, public policies have adopted a perspective less marked by gender bias; however it did not occur in a similar way in Brazil. First, because the Brazilian public policies prioritize programs focusing investments in the subject as participatory citizen, but continue centralizing the family structure as a guideline for public intervention. Second, because the process of individualization and empowering of women in Brazil develops in a much more limited way than in European countries.

This conceptualization of social programs, initially used to analyze the French social protection system, have been gaining strength recently in Brazil, especially in the sociological field of understanding policies. While political scientists take the policy texts as data and assess its effectiveness in general, sociologists perform the critique of policy design, understanding that there may be a large décalage between institutional norm and social practice. At first, it would be possible to classify the PBF concomitantly as a "maternalistic", "familistic" and "gendered" policy. This means that what appears as a strategy to empower women reinforces a view of women' $s$ social role in a quite traditional way, as a mother who sacrifices her interests for the sake of the family. It is also worth saying that programs seize some control of women's lives by some conditionalities [14]. In this sense, Carloto[15] points out the importance of gender analysis to understand policies that focus on the family. In this sense, she points out that woman, from her roles in the reproductive sphere, has been the main interlocutor of these actions. In this context, sociological analysis about state actions that focus on the family structure cannot ignore the gender category, which contributes to the understanding of the exploitation of women's roles in these policies.

It should be noted that the PBF establishes a central role for women, delegating to them the responsibility of family welfare and the possibility of producing an intergenerational mobility (defined by the program's guidance as "breaking the intergenerational cycle of poverty"). The criticism here is that the program does not specify the situation of beneficiary women: if they give up their employability to devote themselves exclusively to the family or if they take control over their sexual and reproductive rights and do not get overwhelmed by household chores or by the double work shift. In this sense, it seems necessary the "defamiliarization of social policies", providing a reduction in the burden of responsibility to this structure and especially to the female figure. This concept has been based on Esping-Andersen's work [16] in which three structures of the European social welfare are theoretically discussed: gender, poverty and social policies.

In the Brazilian literature of social sciences, it is seen that on the one hand benefit payment to women may indicate an achievement of greater autonomy. But on the other, the literature also points out that this prioritization would be a setback as it reinforces the image of women as caretaker of the home as well as puts men in the position of "irresponsible" when it comes to caring for children. This happens because there is a set of counterparts that, in general, income transfer programs require linked to the issue of care for the health and education of children. According to Farah [17], there is a tension between two views in social policies that focus on women as beneficiaries. One of them perceives women mainly from their roles in the family; for this reason, public policies should "invest" in women because of the multiplying effect that such action may have on families and on society as a whole. The other position is hegemonic in the agenda of the feminist movement in Brazil and takes the perspective of rights as a pillar by ensuring the extending of rights to all segments of the population. Farah says that opting for one of these two perspectives do not always occur in an exclusive way, especially with regard to income transfer policies. In this case, the prioritization of women is defended both for the impact in the fight against poverty and for the increase in the autonomy of women.

Some authors state that the feminization of poverty justifies the focus on women as recipient of social benefits. 
In this sense, Godinho[18] points out that the concentration of income, the emergence of pockets of poverty, and the disruption of public services primarily affects women. Therefore, they should be prioritized as beneficiaries of social policies. Justifications of the State and of scholars to put the women in focus are varied. They can be connected to the issue of women's vulnerability, stating that poverty affects them to a greater extent; they can be guided by the idea that women tend to distribute the income to the family better than men. There is also the feminist argument that providing resources for women may give them power. It must be noted, however, that this debate of focusing on women has been going for few decades, since first proposals that contemplated "gender issues" were formulated in the 1980s. Initially, these policies addressed to domestic violence and women's health. Indeed, the inclusion of gender issues on the government agenda took place as part of a process of democratization, which meant the inclusion of new subjects on the political scene and the incorporation of new issues by the public agenda at the same time.

Specifically in Brazil, there was a boom in conferences and actions to discuss and map out policies aimed at women from the 90s. In 2000, the I Municipal Conference of Women in São Paulo can be cited as an example, which enabled the meeting of various groups of women with municipal managers to define some operational guidelines for the Coordination of Women. Internationally, one of several guidelines from the action platform formulated in Beijing referred to the generation of employment and income for women to combat poverty. Another directive signed in Beijing was the incorporation of a gender perspective throughout public policy, also known as transversality.

There are some academic reflections focused on the status of women in the context of income transfer programs implemented in Brazil. The main point of those debates discusses: does the fact that the actions are directed preferentially to women imply increasing autonomy within the domestic environment? The study of Suárez and Libardoni[1] shows that it does indeed, as the task of social reproduction - already held by women before the program is implemented - happens to be managed more safely in food, education and health. So even if the logic of a female care is not changed, women gain autonomy on the domestic sphere, for depending less on the husband and having greater power of definition of priority expenses of the family. In this case, the possibility of making choices, even when constrained by a gender bias, has been considered a gain - albeit small - to female autonomy. Thus, as shown by the authors, the transfer of income allows women to care for the children in a more autonomous and careful way.

However, some authors argue that this type of program does not enhances the empowerment of women in medium and long term, mainly because the PBF does not promote a higher or better insertion in the labor market, maintaining a situation of dependence whether in relation to the spouse, either to the state. This perspective concludes that the program maintains the traditional roles of men and women: provider and caregiver, respectively. Considering Suárez and Libardoni[1], it is noticed that, despite the PBF reproduces the traditional gender and power roles, some changes have been reported by female beneficiaries that constituted the sample of a qualitative research conducted in 10 municipalities of the federation. Those changes are: i) it becomes easier for them to get credit with local merchants; ii) they point changes in the family hierarchy; iii) they point to an increased autonomy as regards the possibility to make choices, even though in most cases limited to the domestic sphere; iv) they obtain documents necessary for the enrollment in the program; v) many of them returns to school.

But, the authors also identify weak points in the program, such as: i) not encouraging integration of women into the labor market; ii) the fact that women perform household activities and activities related to care without assistance of the spouses; iii) autonomy of women is restricted to their performance in "taking care"; iv) the fact that the leisure activities of these women are limited to watching TV at home, sleep and rest, visit relatives and go to church; and v) their attendance at headquarters of social organizations, political parties and trade unions is still very restricted. It is important to note that some points covered by the mentioned Brazilian authors have been explained and discussed by foreign authors such as Hall[19] and Molyneux [20], to assess, respectively, the transfer of income in Brazil and in Mexico. Thus we see that the discussion of the effects of income transfer programs on gender relations is still open and need further elaboration. To this end, some research data from interviewed couples and beneficiaries of PBF residents of the municipality of Itaboraí, on the outskirts of the metropolitan area of Rio de Janeiro are reported. In this article, basically three topics are discussed and guide the investigation. First, it is considered how the process of entering the PBF takes place and how couples living in that region understand that public policy. Second, it is observed how gender relations are developed considering the inflow of money in the composition of the family budget. Finally, the perceptions of "family head" of men and women involved in the program are analyzed.

\section{Methodology}

At first, it should be noted that this research is a localized case study and with no claim of representation and therefore there is no intention to generalize to the country as a whole. A suburb where there were a significant number of beneficiaries of the PBF has been chosen to the completion of the field work. This information was obtained from the local coordination of the program. Thus, visits and on-site observations began. It was possible to develop approaches to women of the seven couples listed below in places such as 
the local health center and the Reference Center for Social Assistance. However, it was noticed that this kind of information had influence on the analysis; therefore, the researchers decided to look for indications of the couples themselves on other beneficiaries who would be willing to be interviewed.

In order to better understand the complexity of the formation of the beneficiary families, we go through several spheres (formal and informal) in the context of poverty in
Itaboraí (periphery of the metropolitan area of Rio de Janeiro) where these individuals pass, such as schools, Coordination of Bolsa Família and the registration sector, Reference Center for Social Assistance (CRAS), popular restaurant and the neighborhood itself. In addition to the participant observation during four months living in the outskirts of Itaboraí, we conducted 60 interviews with beneficiary families, in particular the beneficiaries of the Bolsa Família Program.

Quadro 1. Perfil dos casais entrevistados

\begin{tabular}{|c|c|c|c|c|c|c|c|c|}
\hline & Age & Education & $\begin{array}{l}\text { Number of } \\
\text { children }\end{array}$ & $\begin{array}{l}\text { Married } \\
\text { time }\end{array}$ & $\begin{array}{c}\text { Time in } \\
\text { Bolsa } \\
\text { Família }\end{array}$ & Religion & $\begin{array}{l}\text { Who is the } \\
\text { Family head? }\end{array}$ & Actual job \\
\hline Couple 1 & & & 4 & 11 years & 3 years & & & \\
\hline Marília & 45 & $\begin{array}{c}\text { Incomplete } \\
\text { Primary School }\end{array}$ & & & & Evangelical & My husband & $\begin{array}{c}\text { Domestic } \\
\text { worker }\end{array}$ \\
\hline Alcides & 51 & $\begin{array}{c}\text { Incomplete } \\
\text { Primary School }\end{array}$ & & & & $\begin{array}{l}\text { Without } \\
\text { religion }\end{array}$ & Myself & Carpenter \\
\hline Couple 2 & & & 5 & 10 years & 6 years & & & \\
\hline Lucinéia & 32 & $\begin{array}{c}\text { Incomplete } \\
\text { Primary School }\end{array}$ & & & & $\begin{array}{l}\text { Without } \\
\text { religion }\end{array}$ & Myself & $\begin{array}{c}\text { Does not } \\
\text { exercise paid } \\
\text { activity }\end{array}$ \\
\hline Fernando & 36 & $\begin{array}{c}\text { Incomplete } \\
\text { Primary School }\end{array}$ & & & & $\begin{array}{l}\text { Without } \\
\text { religion }\end{array}$ & My wife & Bricklayer \\
\hline Couple 3 & & & 4 & 7 years & $\begin{array}{c}\text { Six years and } \\
\text { a half }\end{array}$ & & & \\
\hline Suellen & 37 & $\begin{array}{c}\text { Incomplete } \\
\text { Primary School }\end{array}$ & & & & Catholic & My husband & $\begin{array}{c}\text { Does not } \\
\text { exercise paid } \\
\text { activity } \\
\text { remunerada }\end{array}$ \\
\hline Carlos & 36 & $\begin{array}{c}\text { Incomplete } \\
\text { Primary School }\end{array}$ & & & & Catholic & My wife & Merchant \\
\hline Couple 4 & & & 6 & 17 years & Three years & & & \\
\hline Regiane & 52 & $\begin{array}{c}\text { Incomplete } \\
\text { Primary School }\end{array}$ & & & & Evangelical & My husband & $\begin{array}{c}\text { Domestic } \\
\text { worker }\end{array}$ \\
\hline Mauricio & 53 & $\begin{array}{c}\text { Incompleted } \\
\text { Primary School }\end{array}$ & & & & $\begin{array}{l}\text { Without } \\
\text { religion }\end{array}$ & Myself & Mecanic \\
\hline Couple 5 & & $\begin{array}{c}\text { Incomplete } \\
\text { Primary School }\end{array}$ & 6 & 3 years & $\begin{array}{l}\text { Two years } \\
\text { and three } \\
\text { months }\end{array}$ & & & \\
\hline Jenivaldo & 30 & $\begin{array}{c}\text { Incomplete } \\
\text { Primary School }\end{array}$ & & & & Evangelical & My wife & Bricklayer \\
\hline Couple 6 & & & 8 & 11 years & $\begin{array}{l}\text { Two years } \\
\text { and a half }\end{array}$ & & & \\
\hline Marlucy & 34 & $\begin{array}{c}\text { Incomplete } \\
\text { Primary School }\end{array}$ & & & & Evangelical & Myself & $\begin{array}{c}\text { Does not } \\
\text { exercise paid } \\
\text { activity }\end{array}$ \\
\hline Claudio & 50 & $\begin{array}{c}\text { Incomplete } \\
\text { Secondary } \\
\text { School }\end{array}$ & & & & $\begin{array}{l}\text { Without } \\
\text { religion }\end{array}$ & My wife & Waiter \\
\hline Couple 7 & & & 2 & 13 years & $\begin{array}{l}\text { More than } \\
\text { three years }\end{array}$ & & & \\
\hline Josilene & 28 & $\begin{array}{c}\text { Incomplete } \\
\text { Primary School }\end{array}$ & & & & Evangelical & My husband & Saleswoman \\
\hline Denílson & 34 & $\begin{array}{c}\text { Incomplete } \\
\text { Primary School }\end{array}$ & & & & $\begin{array}{l}\text { without } \\
\text { religion }\end{array}$ & Myself & $\begin{array}{l}\text { General } \\
\text { service } \\
\text { assistant }\end{array}$ \\
\hline
\end{tabular}




\subsection{Presentation of Beneficiary Couples}

From start, we would like to emphasize that our research is a case study, localized and without pretension of representativeness, and it cannot be generalized throughout the national territory. More specifically, when we started the fieldwork in Itaboraí, we looked for a peripheral neighborhood that contained a significant number of beneficiaries.

We have obtained this information from the local coordinator of the program. So we started the visits and the observations in the neighborhood. It was possible to develop approximations with the women of the seven couples listed in spaces such as the health system and the Social Assistance Referral Center (Cras). However, we have seen that this type of information skewed the analyzes, because they thought I was an agent of the state who wanted to control or punish their expenses. That's why we began to seek the advice of the couples themselves about other beneficiaries who would be willing to be interviewed.

\section{Bolsa Família Program: Access and Representation}

Marilia is 45 years old. She has been married for 11 years and this is her fourth marriage. She has two children from previous marriages and two with her current husband. She has been receiving the benefit of the PBF for 3 years. Regarding the representation Marilia has from the PBF, she legitimates the program's approach as operated by the municipal council, that is, to monitor and therefore control beneficiary families by means of regular visitation of social workers from CRAS or more frequently of health workers. Marilia believes that the visitation practice is fair as it avoids possible fraud. Nevertheless, she criticizes the low value of the benefit and complains about the need for formal proof of custody of the children. Referring to the social worker, she says: "She says it is necessary a notarized paper to prove the father's custody, to prove that he lives there. I think that is silly. If the father lives in the house, everyone knows that". Thus, Marilia believes that there should not be the need to formalize the guard to receive the benefit because everyone knows when the father cares for the child. Interestingly, similar complaints were so frequent that the federal government has announced changes in the registration sheet.

Marilia heard about the entry into the PBF by a neighbor, but she does not remember what procedures she had to follow to receive the benefit, only stating that she did not have to prove anything to have access to it. She never had received other social benefit before. Marilia reports that her husband, Alcídes, knows nothing about necessary bureaucratic processes for the family to receive the benefit, for example, where she went to apply to the PBF or which documents were required. In his opinion, the feeling of receiving the benefit is satisfactory, because his family was included just in a phase in which he found himself unemployed, so it was helpful in paying for the costs of children. He highlights that the program helped reducing the economic difficulties of the family at the time - similar statements also occur in other interviews.

Another interviewee, Lucinéia, heard from a friend about the Program. By the time she was interviewed, she received the benefit for six years. According to her, before entering the program, a social worker visited her home and made some questions. Afterwards, she received a bank card to withdraw the money. Lucinéia positively evaluates the PBF and highlights, "Now I'm sure I can count on this money every month. I feel secure.” Fernando, Lucinéia's husband, says he saw an advertisement about PBF on television and spoke to his wife about it. He mentions to be aware about all PBF's conditionalities and about the documents required for the registration of his family at the Program. Unlike what some of the literature on assistance state, suggesting that such a policy can generate an output of low self-esteem or a devaluation of the individual - so called "social disqualification" by Paugam[21] - the interviewee points out that the income enabled them to live with more dignity, by purchasing more food and clothes, for example.

Suellen became aware of the Program by her neighbors who, in turn, saw an advertisement on TV. She knows her family is eligible for the Program because of the "poverty line", according to the calculations she witnessed by the time she applied. Thus, it is possible to notice that a commonly academic term as "poverty line" has already been incorporated by the interviewee, who also understands the idea of what would be considered the family per capita income. As opposed to the majority of respondents who believe that families receive the benefit because they need it, Suellen's husband, Carlos, believes that his family only receives it because "God wants it that way" or because "God helps those who are actually in need".

Regiane believes the reason her family receives the benefit is "luck." According to her, they were "lucky" compared to others who applied to the same income transfer policy and were not selected. On the other hand, Maurício, her husband, points out the necessity of drawing upon personal ties to enable the access to the program. In Brazil, it is unexceptional to draw upon personal ties to have access to goods and services and often even to citizens' rights. DaMatta[22] states that, contrary to what occurs in Western capitalist democracies - in which the operating model of citizenship is driven by the notion of a universal understanding of rights, legality, impersonality and public life -, Brazil is particularly characterized by the presence of notions of "relational", "culturalist" and "familistic" in public life.

Consequently, Maurício understands the becoming of the benefit by his family as a result of Regiane's contact with a social worker through a mutual acquaintance in order to overcome bureaucratic hassles. This perspective is illustrative and exemplifies the argument presented by DaMatta [22]. Following the same line of reasoning, Maurício hypothesizes about the reason why many families 
do not receive the benefit. He infers that the many attempts Regiane made in trying to apply only came to an end by the time she met the mentioned acquaintance. Otherwise, she would be still having difficulty trying to apply. As claimed by Maurício's perspective, the scope of the right to the benefit shall be restricted to those who have some degree of "social capital", according to Bourdieu[23]. As "social capital", the author points to the gains that would be achieved by individuals in terms of their social networks. As a result, the access to people of greater social relevance would generate higher conversion possibilities of social capital into personal assets and possibilities.

However, it is clear that for ruling classes the use of social relations circles is developed with power, status and distinction purposes. Whereas, for the lower classes, knowledge of "important individuals" - in the presented case, the "important individual" is a mutual acquaintance with the social worker - might not mean a distinguishing criterion, but the access to a social minimum. According to Creuza, she applied for the program for taking the advice of her neighbor, who was already a beneficiary. This neighborhood network enabled her to register and subsequently receive the money. Creuza understands the program as a federal aid to the poor. Despite Jenivaldo's - Creusa's husband - positive perception of the $\mathrm{PBF}$, he says that there must be access to training courses, in order to decrease unemployment. It is worth pointing out that Jenivaldo does not know how long his wife has been receiving the benefit money, how she applied to the Program, which documents she had to present, and where she applied for the Program. He believes that his family has been selected based on the criteria of need and number of children.

Marlucy became aware of the program through television. After registration, she had to wait three months for the benefit. The interviewee believes her family has been selected for the program because she has "many kids". Interestingly, Marlucy was the only one among all interviewed beneficiaries to make use of this explanation. Overall, respondents highlight the element of "luck" or economic necessity as determining factors to be selected. Josilene took notice of PBF through television and neighbors. She says that was the first time she received some kind of social benefit. Josilene considers the PBF positive. However, she believes that there should be greater control over the management of the resource by the recipients, supervised by the government.

Some important points about the access to the program and representations about it can be highlighted. First of all, there is the perception of women feeling "safer", given that the benefit would be a way to settle their and their children's needs and the income of the money is constant and regular. For men, the feeling is of peace or comfort, for now their wives can collaborate with the purchase of goods for their children. Thus it is clear for interviewed men that the received money relives the pressure of the role of sole provider of the family and the frustration they experienced before entering the Program, to being able to meet some typical demands of children. The second point covers the criteria used by respondents to justify the fact that they were selected by the Program. In most cases, both legal holders of the benefits and their husbands their families were selected due to "luck" or "economic necessity". Another important element is the perception of mothers and fathers of the Program as a way of taking care of their children; therefore, expenses should be directed to the improvement of children's welfare.

Finally, it is observed that some respondents indicate the need for monitoring the beneficiaries. Their arguments, in a certain way, point for a "sense of justice". They believe it would be necessary to conduct a verification of the use of the benefit: if there are deviations for unnecessary expenses or if there is adequate compliance with conditionalities by targeting family expenses, primarily children's.

\section{Gender Relations}

During the interview, Marilia stated that her husband collaborates in household chores, when the children joined the discussion and confirmed such participation. Another interesting point is about children's leisure. Both father and mother agree that just the father takes the children out for entertainment, even though leisure moments are infrequent. Concerning to cultural tastes, there is a clear gender distinction and a charge of male pattern on the possibility of women to make choices. Marilia, for example, likes to watch soap operas on TV, but her husband prefers to watch soccer games. In the end, he decides in which channel the television will be tuned. Marilia also claims that her husband treats her with prejudice because of her religious beliefs: "He says I'm crazy, that all do is to listen to gospel hymns". Regarding the fact that women are primarily chosen as beneficiaries of the money, Fernando shows approval, stating that, for spending more time at home, women should know better how to spend the money for the benefit of the family: "Women always want the best for their children. Men sometimes do not know what to buy with the money".

As seen, Fernando agrees with the Program's initiative of transferring the benefit directly for his wife because she "knows better" when it comes to home and children matters. In this particular case, the PBF's procedure seems to confirm the social role assigned to women, namely the mother and housewife. Besides, this situation highlights the disengagement of men/husbands from household chores. If the Program prioritizes women because they would have better conditions to manage family resources, this choice is consistent with what is already present in both representations of the female beneficiaries of the Program as in their husband's.

Suellen indicates some difficulty in conciliating maternal duties and searching for employment: "I do not even look for a job because I take care of the children. So I do not see 
myself as unemployed. I have been working a lot at home. So I am not unemployed". She understands that taking care of home and children is an occupation; therefore, believes not being part of the category of unemployed people. She does not see herself socially diminished for receiving the benefit; however, points out a relation of dependency and difficulty when it comes to her attempts of conciliating work and family, or the difficulty or impossibility of pursuing the labor market due to her responsibilities with her husband and children. "I must take action, fight to give the best for my kids. But at the moment I am not able to do that, even to avoid conflicts at home because I know he [her husband] will not want me to go to work. Then I'll have to rely a little more on the Bolsa Família".

At this point, two vectors seem to merge: the male domination that would morally prevent her from working based on dislike; and, as she receives a "help" from the government, there would be no material urgency to justify her search for a job. These factors seem to condition her current position toward the labor market. Suellen relates some changes in her relationship with her husband after entering the PBF. She understands she became "more independent", even though highlights all the expenses are directed to ensure a "better future for the kids" and that is a fact that Carlos is aware. Another gender demarcation circumscribes Suellen's marital relationship. She believes men in general appreciate submissive women. When it comes to not being able to fulfill the children's wishes, Suellen is worried and sad. That is a similar situation to what happens to her husband, although it seems that in his case there is a "perverse effect" of male domination. Carlos seems to suffer - a greater extent than his wife - from the social and moral pressure related to the male social role of family provider.

The Program provided some material independence for Suellen from Carlos, who believes the relationship between them has improved because "she does not try to tell me how to spend the money and does not ask for money so often. She helps me more now". Two lines of interpretation are possibly evoked. The first hypothesis is that Carlos evaluates positively the fact that his wife no longer requests his money and there is more left for his own use. For this reason, he would refrain from contributing to the household expenses. The second one indicates that Carlos is in extreme social vulnerability and, therefore, evaluates positively the fact that his wife has her own money, since his is not enough to support the family. In fact, what can be inferred from Carlos' statement is a certain relief with respect to demands associated with typical male role of provider. He claims to be sorry for failing to fulfill what he believes to be the role of father.

This understanding of fatherhood is similar to that expressed by Claudio, Marlucy's husband: "I think it's because of work. I bring money home; buy food on a daily basis. When I can do more, I do more". As seen, his father's role representation is limited to objective factors, mainly the connection between work and earning the money that allows the survival of their children. Concerning the prioritization of having women as beneficiaries of the Program, Maurício says:

"The government does that because women have more time than men. It is her responsibility, because, if the man works the woman is at home. She receives the money, she knows the obligations. The benefit is in her name, but I always keep an eye on. She takes care of the children's immunization schedule, weight gaining... It has to stay on her responsibility. I would not have time for that, because I work from Monday to Monday'.

It can be noticed that Maurício identifies the health care of children as a task of "the woman's responsibility." To that end, he points out that the woman should take care of home and children and not go to work. On this point, he says:

"I prefer women to stay at home and the men to go to work. Men are more productive outside than inside. The right thing is women stay indoors. Except if both can work. If children go to school in the morning, the woman can work half time, that is a whole other situation. The mother has to take care of the children, not the father, especially when there is a female teenager among them".

As seen, household chores and the care of children sharing between the couples beneficiaries of the program seems to play a socially expected pattern in which women are responsible for the tasks related to the core. Husbands believe they do not need to be involved in the conditionalities of the Program, an opinion shared by women as well. Some statements, however, indicate a relative increase in women's independence from their husbands, since they now have "their" own money and need to ask for their husbands' money with less frequency. Reports indicate that both men/husbands and women/wives share the traditional and patriarchal point of view, which states that domestic tasks, including child rearing, is women's sole responsibility. Men are providers and women caregivers. The so-called "financial independence" of women in relation to their husbands/partners with PBF's scarce resources is actually the accountability to spend the received money with the household welfare maintenance. In this sense, the PBF is only reinforcing the traditional structure of family, maintaining gender inequalities.

\section{Perception of Family Heads}

Marilia points out that her husband is the head of the family because the household income comes from his effort and work. Alcídes, her husband, showed some hesitation at first, but then stated in the same position. Lucinéia's opinion about who she considers to be the head of her family is: "Me. We argue, but I have the last word". Fernando, her husband, agrees that his wife is the head of the family, because she is 
taking care of the house and children. Suellen believes her husband is the head of the family as "he brings in most of the money; the benefit is only a complement". Carlos, her husband, considers his wife to be the head of the family because she is the one who takes the lead in all the household chores (which includes grocery shopping) and fixed monthly tasks (paying the bills, for example). Regiane considers her husband head of the family, "he has the authority", she says. Maurício agrees and declares himself as the head because most of the money for the family livelihood is provided by him.

Creuza considers her and her husband as the heads of the family. She states that both of them share the household chores by the time he comes home after work. On the other hand, Jenivaldo claims his wife is the head of the family because she takes care of the children That is, he understands that being the authority role is the same as having mother "status". Marlucy considers herself as the head of the family because, according to the interviewee, she is the one who organizes the family routine: "I am in charge for the house and children. I have more contact with them. That's why I consider myself the head of household". Carlos agreed with her and says his wife is the head of the family because she spends more time with the children. About the head of her family, Josiane states: "it is my husband because he provides the only income we have. So he is the one who maintains the house, right?". Her husband, however, first points out that it would be his wife but when asked about the reason for the answer, he says "No. Actually, I am, right? That is because I support the family. "I spare no efforts".

\section{Some Considerations on the Interviews}

As shown, the researches identify justification criteria that beneficiaries manipulate to explain why they were elected by the program. Basically, two are highlighted: luck and economic necessity - only one of the interviewees stated that having children may have contributed to her entry in the PBF; another one pointed out that his family would have been graced by God. It was noticed that women from all interviewed couples had not only the possession of the card but also the control over the money. Frequently, husbands do not even know what the value of the benefit was. On one hand, it makes women relatively independent; On the other hand, there seems to be a possibility of retention by men of their own personal gain, considering that the women would have their own income from then on.

It is important to notice how beneficiary women and their husbands understand the concept of "head of family". Far from just meaning economic power, status or authority, it largely relates to the domestic sphere and the social role of housewife and mother. In fact, there seems to be two keys to the establishment of this notion: when it is assigned to women - by herself or by the husband - it is related to the management of the household and children; when the leadership is assigned to men - by himself or by his wife - it is related to money and provision.

It is a gendered definition of "head of family". When men said women are in the leadership position, they think of care activities socially attributed to women. Similarly, women who consider themselves as head of family think about elements of their routine dedicated to the household and not about money or placement in the labor market. On the other hand, when men consider themselves as head of family, they think about the income they "bring home" and their professional performance. This is the same explanation that interviewed women present when see their husbands as leaders: they are responsible to provide main financial resources. Men assistance in compliance with program conditionalities only occurs when, for a specific situation, women cannot (or might not always) perform the tasks related to care. In this case, it can be noticed how small changes in everyday life can influence over a wider structure - for example, when the husband takes the lead in household chores because his wife works late or on weekends. As shown, the father participates in the education of children only when there is a breakdown of social expectation. Extraordinary situations seem to be a path of fathers' involvement in child care daily routine.

This research aims to understand how gender relations are developed in couples which receive the Bolsa Família benefit. At this point, an important element is the fact that the program has a positive sense, being taken as part of women's sphere of responsibility. On the other hand, men do not strive to that. Almost all the men interviewed claim to know nothing about the received benefit (value, form of access, required documents and conditionalities). This panorama is probably related to the male understanding that politics replace their role as provider and may also produce the moral judgement that those men are "weak" and do not have the merit of being capable to support their own families. This situation is related to the notion that the PBF is "for the children" and therefore assigned to the feminine sphere. Thus, it is possible that at some extent men represent the program as "a woman's thing".

Gender relations are presented as stratified as there is a total attribution of responsibility on the management of the benefit to women. They are considered as being able to distribute the money to the family's benefit investing primarily in children, at the expense of their own interests. Men role would be supporting women in managing the money they did not earn. The husband tries to turn away from practical and subjective implications of the benefit because the State's presence in the bosom of his family puts into question his "masculinity". In male perspective, the presence of the State would only be providing women ways to perform their typical tasks - with which men do not have much identification.

Finally, we see that although women (mothers) are prioritized in income transfer policies, some challenges 
remain. Among them the follow question appears: how to produce gender autonomy? The first way would be to encourage, through the program, the masculine participation in the care activities. Another way is to combine the Bolsa Familia's policy focused on poor women with a universal policy that guarantees employment and income generation. In order to guarantee women's autonomy, the program could also provide regular and expanded training and education courses for women beneficiaries (once almost all of them do not have complete primary education). Taking into account that Brazil has high rates of gender inequality, it would be interesting that - in the long term - the country incorporates the gender perspective in a transversal way in public policies.

\section{REFERENCES}

[1] Suárez M and Libardoni M (2007). O impacto do Programa Bolsa Família: Mudanças e continuidades na condição social das mulheres.

[2] Pearce D (1978). The Feminization of Poverty: Women, Work and Welfare. In: Urban and Social Change Review 11, pp.28-36.

[3] PETERSON, Janice. The feminization of poverty. Journal of Economic Issues, n. 21, p. 329-337, 1987.

[4] NORTHROP, Emily. The feminization of poverty: the demographic factor and the composition of economic growth. Journal of Economic Issues, v. 24, n. 1, p. 145-160, 1990.

[5] PRESSMAN, Steven. The feminization of poverty: causes and remedies. Challenge, v. 31, n. 2, p. 57-61, mar./abr. 1998.

[6] Fuchs V (1986). The Feminization of Poverty? In: NBER Working Paper Series 1934. Available at: http://ssrn.com/abstract=227084

[7] Marcoux A (1988). The feminization of poverty: Claims, facts and data needs. In: Population and Development Review 24(21), pp.131-139.

[8] Queiroz C, Costa JS, Pinheiro L and Medeiros M (2005). A face feminina da pobreza: Sobrerrepresentações e feminização da pobreza no Brasil. In: Discussion Papers. Brasília: IPEA.

[9] MOGHADAM, Valentine. The feminization of poverty: notes on a concept and trend. Normal: Illinois State University, 1997. MOGHADAM, Valentine. The feminization of poverty: notes on a concept and trend. Normal: Illinois State University, 1997.
[10] LAMPIETTI, Julian; STALKER, Linda. Consumption expenditure and female poverty: a review of the evidence. Policy Research Report on Gender and Development, Washington: Banco Mundial, 2000.

[11] Dooley M (1994). Women, Children and Poverty in Canada. In: Canadian Public Policy 20(24).

[12] Fernandez-Morales A and Haro Garcia J (2000). A note on poverty and gender in Spain. In: Journal of Income Distribution 8(2), pp.235-239.

[13] Orloff AS (2007). Farewell to Maternalism? State Policies and Mothers Employment. In: Working Paper Series. Institute for Policy Research: Northwestern University.

[14] Orloff AS (2007). Farewell to Maternalism? State Policies and Mothers Employment. In: Working Paper Series. Institute for Policy Research: Northwestern University.

[15] MARIANO, Silvana; CARLOTO, Cássia. Gênero e combate à pobreza: programa bolsa família. Rev. Estud. Fem. [online]. 2009, vol.17, n.3, pp.901-908. ISSN 0104-026X.

[16] Esping-Andersen G (2002). Why We Need a New Welfare State. Oxford: Oxford University Press.

[17] Farah M (2004). Políticas públicas e gênero. In: Godinho T and Silveira ML (orgs). Políticas públicas e igualdade de gênero. São Paulo: Coordenadoria Especial da Mulher.

[18] Godinho T (2004). Construir a igualdade combatendo a discriminação. In: Godinho $\mathrm{T}$ and Silveira ML (orgs.). Políticas públicas e igualdade de gênero. São Paulo: Coordenadoria Especial da Mulher.

[19] Hall A (2006). From Fome Zero to Bolsa Família: Social Policies and Poverty Alleviation under Lula. In: Latin América Studies 38(4).

[20] Molyneux M (2006). Mothers at the Service of the New Poverty Agenda: Progresa/Opportunidades, Mexicos Conditional Transfer Programme. In: Social Policy and Adminitration 40, pp.425-449.

[21] Paugam S (2003). Desqualificação social: Ensaio sobre a nova pobreza. São Paulo: Educ/Cortez.

[22] DaMatta R (1991). A casa e a rua. Rio de Janeiro: Guanabara Koogan.

[23] Bourdieu Pand Wacquant L (1992). Réponses: Pour une anthropologie réflexive. Paris: Seuil. 